\title{
Pengembangan Bahan Ajar Fisika Dasar Berbasis Model Pembelajaran P3e Untuk Meningkatkan Keterampilan Berpikir Kritis Mahasiswa Program Studi Tadris Fisika
}

\author{
Bahtiar* \\ Program Studi Pendidikan Fisika, Universitas Islam Negeri Mataram \\ *Email: bahtiar79@uinmataram.ac.id
}

\begin{abstract}
This research aims to cultivate our learning materials basic physics-based model of learning P3E to enhance students ' critical thinking skills. This research was carried out from June until October 2017 at UIN Mataram. The type of research used IE research development-oriented product development includes three phases, namely the preliminary studies, product development and testing products. Test your basic physics materials involving 36 students (two class) semester 2 academic year2016/2017 and extensive trials carried out on 49 students (two class) academic year 2017/2018 Prodi Tadris Physics FTK UIN Mataram. Products resulting from this research is a physics-based model of learning materials learning P3E consisting of four (4) syntax: organizing, investigation, evaluation, and presentation. Basic physics, materials physics material contain basic 1 sub staple in temperature and heat. The results of validation experts show all materials declared valid and reliability. Basic physics-based learning materials learning model used and effective practical P3E to enhance critical thinking skills. There for learning materials based models developed viable P3E learning used to enhance students ' critical thinking skills.
\end{abstract}

Keywords: development of learning materials, Learning Model P3E, critical thinking skills

\section{PENDAHULUAN}

Mata kuliah fisika menekankan fisika sebagai proses, karena fisika berkaitan dengan cara mencari tahu tentang fenomena alam secara sistematis, sehingga fisika bukan hanya penguasaan kumpulan pengetahuan berupa fakta-fakta dan konsep-konsep. Proses pembelajaran fisika menekankan pada pemberian pengalaman langsung untuk mengembangkan kompetensi agar mahasiswa menjelajahi dan memahami alam sekitar secara ilmiah. Pembelajaran fisika diarahkan untuk mencari tahu dan berbuat seperti kegiatan inkuiri ilmiah (scientific inquiry), sehingga mahasiswa sebagai subjek belajar berinteraksi dengan objek atau bendabenda di alam. Mahasiswa melakukan proses ilmiah, seperti: mengamati, mendeskripsikan, mengklasifikasikan, mengukur, melakukan percobaan, menganalisa data, dan menyimpulkan. Peran dosen dalam pembelajaran fisika sebagai pemandu inkuiri (the leader of inquiry). Dosen memiliki peran penting dalam memfasilitasi, memotivasi, mengarahkan, dan membimbing mahasiswa untuk memfasilitasi kegiatan inkuiri. Peran mahasiswa dalam pembelajaran fisika sebagai pelaku inkuiri (the inquirer) (BSNPT, 2006).

Proses belajar mengajar fisika dasar akan menjadi lebih efektif dan efisien jika tersedia bahan ajar yang berkualitas. Berdasarkan hasil analisis beberapa bahan ajar dan buku referensi fisika, sekitar $80 \%$ isinya berupa kumpulan-kumpulan materi dan rumus-rumus, sehingga isi materi tidak menarik oleh pembaca. Buku ajar harus bisa memberikan solusi terhadap kebingungan mahasiswa terhadap materi yang diajarkan.

Buku ajar merupakan salah satu bentuk bahan ajar yang dapat mendukung dalam proses belajar mengajar. Buku ajar merupakan komponen penting yang sangat mendukung berhasilnya suatu pembelajaran. Dengan adanya buku ajar, dosen dapat meminta mahasiswa membaca materi terkait pembahasan pada pertemuan selanjutnya dan meminta mahasiswa menyampaikan hasil bacaan. Dengan 
demikian mahasiswa menjadi terlatih untuk belajar secara mandiri.

Dipilihnya bahan ajar fisika dasar berbasis P3E sebagai salah satu alternatif dalam pembelajaran untuk meningkatkan keterampilan berpikir kritis yaitu bahan ajar yang dikembangkan berisi materi fisika dasar yang di dalam buku ajar tersebut memuat kegiatan praktikum guided inquiry atau disebut dengan model P3E. Model P3E merupakan gabungan dari dua model praktikum yaitu model praktikum konvensional dan model guided inquiry lab. Penamaan model pembelajaran P3E berasal dari empat (4) tahapan yaitu: pengorganisasian, penyelidikan, presentasi, dan evaluasi. Tahap-tahap model pembelajaran P3E diharapkan dapat mengatasi kelemahan praktikum yang selama ini dilaksanakan di perguruan tinggi.

Alasan lain pilihnya model bahan ajar fisika dasar berbasis P3E sebagai salah satu alternatif model dalam pembelajaran, dilandasi oleh dua alasan, yakni: alasan teoretis dan empiris. Alasan teoretis ini didukung oleh teori-teori belajar, antara lain: Pertama, teori belajar David Ausabel: dosen harus dapat mengembangkan potensi kognitif mahasiswa melalui proses belajar yang bermakna. Bermakna yaitu materi pelajaran yang sesuai dengan konsep yang ada dalam struktur kognisi mahasiswa. Menurut Nur, (2008) belajar bermakna merupakan suatu proses menghubungkan informasi baru dengan struktur pengetahuan yang sudah dimiliki seseorang. Mahasiswa harus tahu makna belajar dan menggunakan pengetahuan serta keterampilan yang diperoleh untuk memecahkan masalah dalam kehidupan, sehingga aktivitas belajar akan menimbulkan makna yang berarti (meaningfull). Seperti yang dicontohkan oleh Bruner dan Gagne, Ausebel (1969) dalam Nur (2008) beranggapan bahwa aktivitas belajar mahasiswa, terutama mahasiswa yang berada di tingkat awal akan bermanfaat kalau mahasiswa banyak dilibatkan dalam kegiatan langsung. Untuk mahasiswa, lebih efektif kalau dosen menggunakan penjelasan, peta konsep, demonstrasi, kegiatan praktikum, diagram, dan ilustrasi. Kedua, teori belajar Bruner (teori belajar penemuan): menurut Jerome Bruner (1966) dalam Nur (2008) mahasiswa akan mudah mengingat suatu konsep jika konsep tersebut mahasiswa dapatkan sendiri melalui proses belajar penemuan. Perolehan pengetahuan dan mengkonstruksi pengetahuan yang diperoleh dengan penyelidikan (inquiry) menunjukkan beberapa kelebihan, di antaranya (1) pengetahuan itu bertahan lama, (2) hasil belajar inkuiri memiliki efek transfer yang lebih baik (3) meningkatkan penalaran mahasiswa dalam kemampuan berpikir secara bebas.

Praktikum berbasis keterampilan proses sains jarang dilatihkan pada siswa, berdasarkan analisis oleh the West African Senior Secondary School Certificate di Negeria dalam kurun waktu 10 tahun (19982007) bahwa keterampilan proses sains fisika masih rendah. Hasil perolehan nilai keterampilan proses sains siswa yaitu; memanipulasi (17\%); menghitung (14\%); merekam atau mencatat (14\%); mengamati (12\%), dan mengkomunikasikan (11\%) (Akinyemi, O.A., \& Folashade, A., 2010). Hal ini didukung hasil pra penelitian Bahtiar (2016), pada 60 mahasiswa, menunjukkan bahwa keterampilan proses sains (KPS) mahasiswa masih rendah yaitu: merumuskan masalah $41,67 \% \quad$ (25 mahasiswa), merumuskan hipotesis $58,33 \%$ (35 mahasiswa), identifikasi variabel $25 \%$ (15 mahasiswa), definisi operasional variabel $28,33 \% \quad(17$ mahasiswa), melakukan penyelidikan $66,67 \% \quad(40$ mahasiswa), analisa data $75 \% \quad(45$ mahasiswa), menyimpulkan 76,67\% (46 mahasiswa). Hal ini yang menyebabkan keterlibatan dan keaktifan siswa sangat 
kecil.

Rendahnya keterampilan proses sains ternyata disertai dengan rendahnya keterampilan berpikir kritis. Hasil prapenelitian Bahtiar (2016) pada mahasiswa prodi pendidikan fisika yaitu keterampilan berpikir kritis mahasiswa sangat rendah, seperti; kemampuan interpretasi $(38,55 \%$ dan 40,47\%); analisis (30,08\% dan 31,28\%); sintesis $(25,70 \%$ dan $30,25 \%)$; evaluasi (32,03 dan $34,45 \%)$; menyimpulkan $(25,27$ dan 29,53\%); inferensi $(35,10 \%$ dan $37,21 \%)$; dan eksplanasi $(35,24 \%$ dan $39,53 \%)$.

Menurut Anderson dan Krathwohl's (2001), untuk dapat melakukan aktivitas mengidentifikasi dan mendefinisikan suatu variabel sekurang-kurangnya siswa harus menguasai tiga kemampuan dasar, yakni pengetahuan, pemahaman, dan aplikasi.

Keterampilan proses sains siswa yang rendah disebabkan oleh beberapa faktor meliputi; rendahnya latar belakang sains, minimnya prasarana laboratorium (Jack, 2013), buku satu-satunya pedoman dalam pembelajaran (Ekene and Ifeoma, 2011), administrasi sekolah belum menginisiasi pembelajaran kontekstual (Chaguna and Yango, 2008), pembelajaran sains di sekolah hanya menekankan penguasaan konsep, serta kegiatan pembelajaran belum mengeksplorasi keterampilan proses sains siswa (Sukarno, et. al., 2013). Penelitian Haryono (2006) menyatakan bahwa model pembelajaran berbasis keterampilan proses sains secara siginifikan efektif untuk meningkatkan kemampuan proses sains siswa dari $46,08 \%$ menjadi $67,27 \%$.

Permasalahan keterampilan berpikir kritis seperti yang dikemukakan oleh Bahtiar, juga terjadi di negara lain, seperti di Australia tahun 2011 melaporkan bahwa dua tahun pertama pembelajaran di kampus terdapat $45 \%$ mahasiswa tidak mengalami peningkatan yang signifikan terhadap keterampilan berpikir kritis dan bernalar.
Setelah empat tahun kemudian terdapat 36\% mahasiswa tidak mengalami peningkatan yang signifikan terhadap keterampilan berpikir kritis dan bernalar (Martin, 2011). Selaras dengan hasil penelitian Joseph, (2006) menyatakan bahwa mahasiswa pada saat ini memiliki permasalahan antara lain; critical thinking \& problem solving sebesar $70 \%$.

Uraian di atas menjelaskan bahwa keterampilan berpikir kritis merupakan keterampilan yang harus ditumbuh kembangkan bagi mahasiswa agar mampu berdaya saing di abad 21, tetapi untuk memacu berkembangnya keterampilan berpikir termasuk keterampilan berpikir kritis, harus dikembangkan keterampilan proses mahasiswa. Senada dengan pernyataan tersebut, Joseph (2006) bahwa keterampilan yang perlu dikembangkan lima tahun ke depan salah satunya adalah; keterampilan critical thinking (78\%). Karamustafaoglu (2011) menyatakan bahwa pengembangan keterampilan proses sains memungkinkan mahasiswa mengkonstruk dan menyelesaikan masalah serta berpikir kritis. Kemungkinan ini dapat terjadi karena komponen-komponen berpikir kritis sebagian besar merupakan komponen keterampilan proses sains seperti: observing, testing hypotheses, predicting, classifying, designing experiments, measuring, analysis, and synthesis (Hassard, 2005). Keterampilan berpikir kritis dianggap sama sebagai keterampilan berpikir ilmiah dalam sains (Schafersman, 1991; Ergazaki, 2000; Pomahac, et.al., 2007). Menyadari hal itu, keterampilan berpikir kritis perlu diajarkan dalam pembelajaran sains sebagaimana keterampilan proses sains. Dengan demikian, jika keterampilan proses sains berkembang, maka keterampilan berpikir kritis mahasiswa juga akan berkembang.

Salah satu model yang dapat melatih keterampilan berpikir kritis adalah model 
inkuiri (Eggen \& Kaucahak, 2012). Senada dengan pendapat Blosser et al. (1990) yang menjelaskan bahwa model guided inquiry mahasiswa mendapatkan pemahaman yang lebih baik mengenai sains dan akan lebih tertarik terhadap sains jika mahasiswa dilibatkan secara aktif dalam melakukan sains. Berdasarkan pendapat tersebut, model pembelajaran guided inquiry memfasilitasi mahasiswa, memberikan kesempatan kepada mahasiswa untuk mengalami/melakukan kegiatan praktikum sendiri, mengikuti suatu proses, mengamati suatu objek, menganalisis, membuktikan, dan menarik kesimpulan. Berdasarkan hasil observasi awal di sekolah, dalam kegiatan praktikum mahasiswa sangat sulit melaksanakan sendiri kegiatan praktikum tanpa bimbingan dosen (dosen sebagai fasilitator) (Bahtiar, 2013).

Pemilihan materi suhu dan kalor dalam penelitian ini didasari bahwa materi suhu dan kalor merupakan materi fisika yang terdapat dalam fisika dasar 1 semester 1 . Materi suhu dan kalor merupakan materi yang berkaitan dengan kehidupan seharihari. Materi suhu dan kalor selalu diamati dan dirasakan oleh mahasiswa dalam kehidupan sehari-hari, tetapi kenyataannya mahasiswa tidak mampu menyelesaikan permasalahan tersebut. Berdasarkan hasil wawancara peneliti dengan dosen fisika, bahwa hasil ujian sangat rendah dengan nilai rata-rata masing-masing kelas yaitu 48,16.

Mencermati permasalahan di atas, perlu dilakukan sebuah penelitian pengembangan model bahan ajar yang memberikan kesempatan kepada mahasiswa untuk berperan aktif dalam proses pembelajaran fisika dan mampu melatih keterampilan berpikir kritis. Keterampilan berpikir kritis yang dimaksud dalam penelitian adalah kemampuan menganalisis, mensintesis, dan menyimpulkan. Ketiga indikator tersebut dikutip dari beberapa kesimpulan pendapat ahli didalam mendefinisikan keterampilan berpikir kritis.
Alasan lain adalah indikator keterampilan berpikir kritis seperti menganalisis, mensintesis, dan menyimpulkan, ditingkat perguruan tinggi jarang dilatih sehingga hasilnya masih sangat rendah (Bahtiar, 2013; Martin, 2011).

\section{METODE PENELITIAN}

Penelitian ini merupakan penelitian pengembangan yang berorientasi pada pengembangan suatu produk. Produk yang dihasilkan dari penelitian ini adalah bahan ajar fisika berbasis model pembelajaran P3E yang terdiri atas 4 (empat) sintaks yaitu: pengorganisasian, penyelidikan, presentasi, dan evaluasi. Pengembangan bahan ajar fisika berbasis model pembelajaran P3E untuk meningkatkan keterampilan berpikir kritis.

Subjek pada penelitian ini adalah buku ajar fisika dasar berbasis model pembelajaran P3E untuk meningkatkan keterampilan berpikir kritis mahasiswa. Subjek ujicoba bahan ajar fisika dasar berbasis model pembelajaran P3E yang dikembangkan adalah mahasiswa prodi pendidikan fisika dengan 36 mahasiswa (2 kelas) semester 2 Tahun Akademik 2016/2017 dengan materi pokok suhu dan kalor. Subjek uji luas dilaksanakan pada 49 mahasiswa (2 kelas) Tahun Akademik 2017/2018. Bahan ajar berbasis model pembelajaran P3E dikembangkan pada bulan Juli 2017 dan kegiatan FGD di UIN Mataram. Ujicoba bahan ajar berbasis model pembelajaran P3E dilaksanakan selama 2 bulan yaitu pada bulan SeptemberOktober 2017. Lokasi ujicoba terbatas dan uji luas di Prodi Pendidikan Fisika.

Pengembangan bahan ajar fisika berbasis model pembelajaran P3E menggunakan metode R \& D (Research and Development) untuk menghasilkan produk tertentu dan menguji keefektifan produk tersebut (Sugiyono, 2009: 297). Secara konseptual, metode R \& D menurut Borg et 
al. (2003:570) meliputi (1) studi pendahuluan, (2) pengembangan produk dan (3) pengujian produk. Tahapan prosedur penelitian dan pengembangan dapat dilihat dalam uraian sebagai berikut:

\section{Tahap Studi Pendahuluan}

Tujuan dari tahap ini adalah untuk mendeskripsikan dan menganalisis permasalahan yang ada di lapangan yang berhubungan dengan buku ajar yang sedang beredar. Fokus kegiatan yang dilakukan pada tahap ini adalah mengumpulkan informasi sebanyak-banyaknya melalui studi pustaka, berkonsultasi dan melakukan peninjauan langsung (Arikunto Suharsimi, 2006).

Studi pustaka dilakukan dengan membaca literatur baik teori maupun penelitian terdahulu yang relevan dengan masalah dan tujuan penelitian. Konsultasi dilakukan untuk memperoleh informasi tentang keadaan di lapangan maupun arahan dari para ahli. Peninjauan langsung ini dimaksudkan agar mengetahui kondisi riil yang akan diteliti terutama kelebihan dan kekurangan yang ada pada bahan ajar fisika berbasis model P3E yang digunakan, hal ini dilakukan untuk mendapatkan gambaran dan masukan terhadap bahan ajar fisika berbasis model P3E yang akan dikembangkan. Ketiga kegiatan tersebut kemudian hasilnya dianalisis dan dideskripsikan sehingga dapat dijadikan acuan dalam pengembangan produk, yaitu bahan ajar fisika berbasis model P3E.

\section{Tahap Pengembangan Produk}

Berdasarkan analisis dan temuan pada studi pendahuluan maka produk yang akan dikembangkan berupa bahan ajar fisika berbasis model P3E. Pada tahapan pengembangan produk dilakukan kegiatan yang meliputi: penyusunan dan pengembangan draf produk, validasi, uji coba I, evaluasi dan perbaikan. Pada kegiatan penyusunan draf dirancang prototipe produk.
Dalam penyusunan draf produk ini yang pertama kali yang dilakukan, yaitu menetapkan fokus keterampilan yang ingin dikembangkan. Setelah dilakukan penyusunan dan penetapan tujuan kegiatan pembelajaran kemudian dikembangkan draf produk.

\section{Tahap Ujicoba Produk}

Setelah dilakukan pengembangan draf produk berdasarkan kajian teoritis, maka draf produk tersebut kemudian dipresentasikan dalam kegiatan diskusi bersama (FGD) di antaranya bersama validator dan dosen-dosen fisika. Hal ini dimaksud agar memperoleh masukan yang berguna bagi pengembangan produk. Setelah dilakukan perbaikan berdasarkan hasil FGD kemudian draf produk divalidasi kepada para ahli. Masing-masing draf produk tersebut akan divalidasi oleh 3 orang ahli. Setelah divalidasi, darf produk yang telah direvisi kemudian diuji cobakan. Uji coba dilakukan setelah revisi. Uji coba difokuskan untuk menguji substansi isi dan fleksibilitas produk.

\section{HASIL DAN PEMBAHASAN}

Pengembangan buku ajar berbasis model pembelajaran P3E sangat diperlukan dalam rangka menunjang keterlaksanaan dan proses pembelajaran yang akan dilaksanakan.

— skor validasi reliabilitas

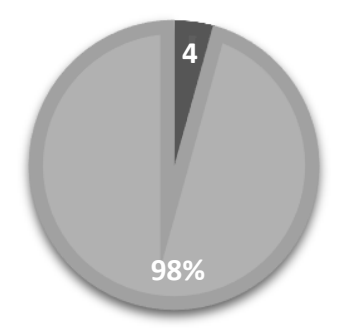

Gambar 1. Validasi Buku Ajar Untuk Meningkatkan Keterampilan Berpikir Kritis

Data pada gambar 1 tersebut menunjukkan hasil pengembangan dinyatakan sangat 
valid. Hasil telaah pakar selanjutnya disebut validasi menunjukkan bahwa kandungan buku ajar berbasis model P3E dengan sintaks pengorganisasian, penyelidikan, presentasi, dan evaluasi, memiliki rata-rata 4,53, sehingga kategori seluruh komponen adalah sangat valid (Ratumanan \& Laurens, 2006). Pencapaian kualitas ini, dikarenakan pengembangan perangkat telah melalui beberapa tahapan, yaitu analisis kebutuhan, analisis konsep, analisis tugas, diskusi dengan dosen-dosen fisika, dan telah divalidasi oleh pakar (validator) meliputi, 5 indikator yakni: (a) kandungan buku ajar, (b) struktur materi, (c) kedalaman dan keluasan materi, (d) memuat latihan keterampilan berpikir kritis (e) dapat digunakan secara mandiri di mana bahan ajar di kembangkan.

Buku ajar yang dikembangkan dalam penelitian ini mengangkat materi pokok suhu dan kalor yang terdiri dari sub-sub bab antara lain; (1) suhu dan alat ukur suhu; (2) pemuaian zat padat; (3) pemuaian zat cair dan gas; (4) kalor; (5) perubahan wujud; dan (6) perpindahan kalor. Buku ajar yang dikembangkan berisi judul sub bab, gambargambar motivasi, kegiatan penemuan, lab mini/inquiry, contoh masalah keterampilan berpikir kritis, contoh soal beserta pembahasan, rangkuman, dan daftar pustaka.

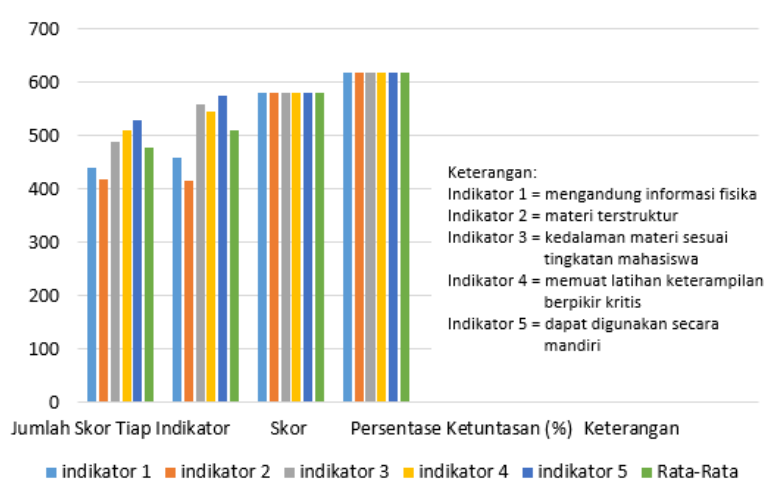

Buku ajar dikembangkan berdasarkan model pembelajaran P3E yaitu fase pengorganisasian di dalam buku ajar memuat memotivasi mahasiswa dengan mengacu pada kegiatan mini inkuiri dan gambar, untuk merangsang mahasiswa berpikir kritis dan bertanya. Bahan ajar yang diorganisasikan dengan baik lebih mudah untuk dipelajari dari pada bahan ajar yang tidak diorganisasikan dengan baik. Pengorganisasian secara hirarki, di mana hal-hal khusus dikelompokkan di bawah topik-topik yang lebih umum, dapat membantu pemahaman mahasiswa (Nur, 2008). Fase penyelidikan di dalam buku ajar memuat lab inkuiri yaitu berupa tahapan kegiatan eksperimen, Carin (1993) menyatakan bahwa mahasiswa akan lebih termotivasi jika dalam belajarnya menemukan sesuatu oleh mereka sendiri dibandingkan jika mereka hanya mendengarkan materi pembelajaran, fase presentasi di dalam buku ajar merupakan bagian lanjutan dari kegiatan penyelidikan, karena dari hasil kegiatan eksperimen mahasiswa mampu mempresentasikan hasil penyelidikannya di depan kelas, menurut Arends (2012), jika diciptakan kesempatan interaksi, maka mahasiswa melalui modelmodel pemeranan, ikonik, maupun simbolik, maka muncul perasaan memiliki, dan kreativitas estetika dalam pembelajaran, dan fase evaluasi di dalam buku ajar berisi tentang kesimpulan hasil percobaan dan soal-soal uji kompetensi.

Setelah memperhatikan dan menindaklanjuti saran dan revisi validator, maka buku ajar yang telah dikembangkan ini dapat dikategorikan valid berdasarkan model pembelajaran P3E, dan dapat digunakan dalam pembelajaran fisika di perguruan tinggi pada standar kompetensi yaitu mengevaluasi konsep dan prinsip kalor, konversi energi, dan sumber energi dengan berbagai perubahannya dalam mesin kalor.

Gambar 2. Keefektifan Buku Ajar Untuk Meningkatkan Keterampilan Berpikir Kritis

Hasil tes keterampilan berpikir kritis tentang suhu dan kalor pada penelitian ini 
diperoleh dengan menggunakan lembar penilaian keterampilan berpikir kritis (LP KBK) pada buku ajar yang dikembangkan dengan jumlah soal 5 butir soal dalam bentuk essay.

Data pada gambar 2 menunjukkan berbagai indikator keefektifan buku ajar yang dikembangkan. Selain itu, pembelajaran dengan buku ajar yang dikembangkan memuat sintaks model pembelajaran P3E dapat meningkatkan keterampilan berpikir kritis. Peningkatan tersebut terlihat dari persentase ketuntasan belajar sebesar $82,42 \%$. Berdasarkan kriteria Depdiknas, (2008), bahwa indikator pembelajaran dikatakan tuntas apabila persentase ketuntansan $\geq 60 \%$. Beberapa hasil tersebut maka dapat disimpulkan, bahwa keterampilan berpikir kritis dapat ditingkatkan dengan buku ajar berbasis model P3E. Penelitian-penelitian terdahulu menemukan, bahwa keterampilan berpikir kritis memang tidak mudah ditingkatkan, akan tetapi kemampuan berpikir kritis dapat dipelajari dan dilatih (Snyder \& Snyder, 2008; Peter, 2012; 2013; Facione, 2015). Hal ini didukung oleh hasil penelitian Yeritia et al. (2017) dan Nurmayani et al. (2018) menyatakan kemampuan berpikir kritis peserta didik bisa ditingkatkan melalui model pembelajaran seperti model pembelajaran inkuiri terbimbing.

Oleh karena itu, guru dan dosen dituntut untuk mengembangkan bahan ajar yang dapat melibatkan mahasiswa dalam berpikir kritis. Hasil penelitian Oktaviani et al. (2017) setiap guru dapat mengembangkan bahan ajar sesuai kompetensinya, untuk meningkatakan hasil belajar siswa dan keterampilan berpikir kritis dengan bahan ajar tersebut siswa dapat belajar secara mandiri. Meskipun kemampuan berpikir kritis dapat dilatih dan dipelajari, namun banyak hal yang menghambat mempelajarinya. Menurut Peter (2012) halhal yang dapat menghambat berpikir kritis adalah kurangnya latihan, terbatasnya sumber, persepsi yang bias, dan waktu yang membatasi lingkungan untuk mempromosikan berpikir kritis. Pernyataan Peter didukung penelitian Snyder \& Snyder (2008) adalah terlalu banyak menghafal dan sedikit berpikir, sedikit menguasai konsep, mahasiswa tidak diberi latihan berpikir kritis, dan waktunya terlalu singkat, sehingga sangat wajar apabila seseorang memiliki kemampuan berpikir kritis yang rendah. Hal ini didukung oleh hasil penelitian Liliasari (2009) bahwa pemahaman konsep sains dapat ditingkatkan melalui pengembangan keterampilan berpikir siswa. Sejalan dengan hal tersebut guru merasakan lebih mudah membelajarkan sains kepada siswa yang telah berkembang keterampilan berpikir kritisnya.

Implementasi buku ajar berbasis model P3E diperoleh hasil perbandingan KBK (keterampilan berpikir kritis) antara mahasiswa kelas A dengan kelas B adalah peningkatan rata-rata dengan $t_{\text {hitung }}=21,29>$ dari $t_{\text {tabel }}=2,052$, sehingga pemberian perlakuan (menerapkan bahan ajar berbasis model pembelajaran P3E) sebelum dan setelah perlakukan adalah signifikan. Hal ini terjadi karena bahan ajar berbasis model pembelajaran P3E memiliki kelebihan atau keunggulan yaitu; 1) dalam buku ajar memuat sintaks model P3E, yang berdasarkan hasil kajian empiris, model pembelajaran P3E dapat melatihkan keterampilan berpikir kritis mahasiswa pada pokok bahasan suhu dan kalor, seperti: mahasiswa dapat menganalisis, mensintesis, dan dapat menyimpulkan; 2) buku ajar yang dikembangkan berbasis praktikum sehingga memudahkan mahasiswa dalam menemukan konsep fisika, 3) buku ajar memuat latihan-latihan yang menuntun mahasiswa berpikir kritis.

\section{PENUTUP}


Berdasarkan hasil dan uraian pembahasan penelitian, maka dapat ditarik kesimpulan sebagai berikut:

1. Bahan ajar fisika dasar berbasis model pembelajaran P3E yang dikembangkan valid berdasarkan penilaian validator,

2. Bahan ajar fisika dasar yang dikembangkan efektif untuk meningkatkan keterampilan berpikir kritis, keefektifan ini di lihat dari rangkaian kegiatan belajar yang termuat pada buku ajar memeuat sintaks model pembelajaran P3E.

3. Berdasarkan hasil tersebut, bahwa buku ajar mampu mempermudah mahasiswa berpikir kritis yang ditunjukkan oleh hasil pengimplementasian buku ajar yang dikembangkan (keefektifan buku ajar meningkatkan keterampilan berpikir kritis) menunjukkan, bahwa buku ajar praktis digunakan untuk mahasiswa dalam meningkatkan keterampilan berpikirnya.

\section{REFERENSI}

Akinyemi, O.A., \& Folashade, A., 2010. Analysis of Science Process Skill in West Africa Senior Secondary School Certificate Physics Practical Examination in Nigeria. AmericaEurasian Journal of Scientific Reseacch 5 (4), 234-240.

Anderson, L. D., Dan Krathwohl, D. R. 2001. A Taxonomy for Learning, Teaching, And Assesing. Newyork. Addison Wesley Inc.

Arends, R. 2012. Learning to Teach, 9th Edition. New York: Mc-Graw Hill.

Arikunto, Suharsimi. 2006. Dasar-Dasar Evaluasi Pendidikan. Jakarta: Bumi Aksara.

Bahtiar. 2016. Laporan Preliminary Study Di Prodi Pendidikan Fisika Ftk Uin Mataram. Mataram: NTB.

Blosser, Patricia E. \& Helgenson, Stanley L. 1990. Selecting Procedures for Improving the Science Curriculum. Columbus, $\quad \mathrm{OH}: \quad$ ERIC
Clearinghouse for Science, Mathematics, and Environment Education. (ED325303).

BSNP, T. 2006. Standar Isi. Jakarta. Badan Standar Nasional Pendidikan

Carin, A. A. 1993. Teaching Modern Science. Sixth Edition. New York: Macmillan Publishing Company.

Chaguna, L.L \& Yango, D.M. 2008. Science Process Skills Proficiency of the Grade VI Pupils in The Elementary Diocesan Schools of Baguio and Benguet. Research Journal. 16(4): 22-32.

Depdiknas. 2008. Pengembangan Bahan Ajar dan Media. Jakarta: Dikmenum Depdiknas.

Eggen Paul dan Kaucahak Don. 2012. Strategi dan Model Pembelajaran: Mengajar Konten dan Keterampilan Berpikir, Edisi 6 (Terjemahan) Jakarta: PT. Indeks.

Ekene, Igboegwu. 2011. Effects of CoOperative Learning Strategy and Demonstration Method On Acquisition of Science Process Skills by Chemistry Students of Different Levels of Scientific Literacy. Journal of research and Development. 3(1): 204-212.

Ergazaki, M. 2000. Biotechnology/Genetic Engineering: Research on Teaching and Learning in Critical Thinking Context. http://www.iubs.org/patras.biotec h-criticalthinking.pdf. Diakses tanggal pada 18 Desember 2015.

Facione, P. 2013. Critical Thinking: What It Is and Why It Counts. Measured Reasons and The California Academic Press, Millbrae, CA.

Haryono. 2006. Model Pembelajaran Berbasis peningkatan Keterampilan Proses Sains. Jurnal Pendidikan Dasar. 7 (1), (1-13)

Hassard, J. 2005. The Art Teaching Science. New York: Oxford University Press. 
Jack, G.U. 2013. The Influence of Identified Student and School Variables on Student Science Process Skill Acquisition. Journal of Education and Practice. 4(5): 16-22.

Joseph. 2006. Partnership for $21^{\text {st }}$ Century Skills (P21). Are They Really Ready to Work? The Conference Board, Corporate Voices for Working Families, P21, and SHRM.

Karamustafaoglu. 2011. Improving the Science Process Skill Ability of Science Student Teacher Using I Diagram. Eurasia Journal of Physics and Chemistry Educational, 26-36.

Liliasari. 2009. Berpikir Kritis Dalam Pembelajaran Sains Kimia Menuju Profesionalitas Guru. Bandung: Program Studi Pendidikan IPA Sekolah Pascasarjana UPI.

Martin, D. 2011. Introduction to The Special Issue On Critical Thinking in Higher Education. Higher Education Reseach and Development, 255-260.

Nur. 2008. Pengajaran Berpusat Kepada Siswa dan Pendekatan Konstruktivis dalam Pengajaran. Surabaya: PSMS UNESA.

Nurmayani, L., Doyan, A., \& Verawati, N. N. S. P. 2018. Pengaruh Model Pembelajaran Inkuiri Terbimbing Terhadap Kemampuan Berpikir Kritis Peserta Didik. Jurnal Pendidikan Fisika dan Teknologi, 4(1), 98-104.

Oktaviani, W., Gunawan, \& Sutrio. 2017. Pengembangan Bahan Ajar Fisika Kontekstual Untuk Meningkatkan Penguasaan Konsep Siswa. Jurnal Pendidikan Fisika dan Teknologi, 3(1), 1-7.

Peter, E E. 2012. Critical Thinking: Essence for Teachiing Mathematics and Mathematics Problem Solving Skill. African Journal of Mathematics and Computer Science Research, 5(3): 39-43. doi:
10.5897/AJMCSR11.161.

Pomahac, G., Thelma M. Gunn, Lance M. Grigget. 2007. Bioethics and Critical Thinking in a Science Classroom. Conference Prisiding. http://www.umanitoba.ca/conferguy.1438.pdf. Diakses pada tanggal 18 Desember 2015.

Ratumanan, T. G. \& Laurens. 2006. Evaluasi Hasil Belajar Yang Relevan Dengan Kurikulum Berbasis Kompetensi. Surabaya: Unesa University Press.

Schafersman, S. D. 1991. Introduction to Critical Thinking. [Online]. Tersedia: http://www.freeinquiry.com/critic al-thinking.html. Diakses pada tanggal 12 November 2012.

Snyder, L G., \& Snyder M J. 2008. Teaching Critical Thinking and Problem Solving Skills. Spring/Summer, L (2).

Sugiyono. 2009. Metode Penelitian Kuantitatif, Kualitatif dan $R \& D$. Bandung: Alfabeta.

Sukarno, Permanasari, A., \& Hamidah, I. 2013. The Profile of Science Process Skill (SPS) Student at Secondary High School (Case Study in Jambi). International Journal of Scientific Enginering and Research. 1(1): 79-83.

Yeritia, S., Wahyudi, \& Rahayu, S. 2017. Pengaruh model pembelajaran inkuiri terbimbing terhadap penguasaan konsep dan kemampuan berpikir kritis fisika peserta didik kelas X SMAN 1 Kuripan tahun ajaran 2017/2018. Jurnal Pendidikan Fisika dan Teknologi, 3(2), 181-187. 